Article

\title{
Compound K Inhibits the Lipopolysaccharide-Induced Inflammatory Responses in Raw 264.7 Cell Line and Zebrafish
}

\author{
Su-Jung Ryu ${ }^{1}$, Jia Choi ${ }^{1}$, Jong-Seok Lee ${ }^{2}$, Hyeon-Son Choi ${ }^{3}$, Kye-Yoon Yoon ${ }^{1}$, \\ Ji-Hyun Hwang ${ }^{1}$, Kui Jin Kim ${ }^{1, *,+}$ and Boo-Yong Lee ${ }^{1, *,+}$ \\ 1 Department of Food Science and Biotechnology, College of Life Science, CHA University, Seongnam, \\ Kyonggi 463-400, Korea; fkadldl@naver.com (S.-J.R.); wldk3176@gmail.com (J.C.); \\ beautyygy@naver.com (K.-Y.Y.); hwangjh1104@naver.com (J.-H.H.) \\ 2 National Institute of Biological Resources, Incheon 404-170, Korea; jongseoklee78@gmail.com \\ 3 Department of Food and Nutrition, Seoul Women's University 621, Hwarang-ro, Nowon-gu, Seoul 01797, \\ Korea; choice120@gmail.com \\ * Correspondence: Kuijin.Kim@gmail.com (K.J.K.); bylee@cha.ac.kr (B.-Y.L.); \\ Tel.: +82-31-881-7155 (K.J.K.); +82-31-881-7155 (B.-Y.L.) \\ + These authors contributed equally to this work.
}

Received: 21 April 2018; Accepted: 1 June 2018; Published: 4 June 2018

\begin{abstract}
Compound $\mathrm{K}$, a major metabolite of ginsenosides Rb1, which is produced by human intestinal bacteria after oral administration, is one of the main pharmacologic compounds found in ginseng. In our previous study, we demonstrated that compound $\mathrm{K}$ inhibited the production of nitric oxide (NO) and prostaglandin E2 in lipopolysaccharide (LPS)-treated RAW264.7 cells. However, the mechanisms by which compound $\mathrm{K}$ may be effective against inflammation remain unknown. In the present study, compound K significantly inhibited LPS-induced NO production by suppression of inducible NO synthase (iNOS) in LPS-treated RAW264.7 cells. Compound K also inhibited LPS-induced cyclooxygenase-2 (COX-2) expression at both the mRNA and protein levels. It effectively suppressed both the release and mRNA expression levels of pro-inflammatory cytokines such as interleukin-1 $\beta$ (IL-1 $\beta$ ) and IL-6. The anti-inflammatory effects of compound K appeared to occur via inhibition of LPS-induced phosphorylation of mitogen-activated protein kinases (MAPKs) and inhibition of NF- $\mathrm{B}$ translocation from the cytosol to the nucleus by suppressing phosphorylation of inhibitory kappa B- $\alpha$ (IкB- $\alpha)$. Furthermore, we showed that compound K inhibited LPS-induced NO generation in an experimental zebrafish model. Considering these results, compound K could potentially be developed as a natural anti-inflammatory agent.
\end{abstract}

Keywords: compound K; RAW264.7 cell; zebrafish; NF-kB(p-65); MAPK

\section{Introduction}

Although inflammation is a defense response against harmful stimuli and injury, its continued reaction is associated with the development of chronic diseases such as obesity, inflammatory bowel disease, and several cancers [1-3]. Macrophage activation plays a key role in the progression of multiple inflammatory diseases by secreting pro-inflammatory cytokines (e.g., interleukin (IL)-6 and IL-1 $\beta$ ) that recruit additional immune cells to the site of infection or tissue injury, releasing cytotoxic and inflammatory molecules (e.g., nitric oxide (NO)), and critical enzymes (e.g., inducible NO synthase (iNOS) and cyclooxygenase-2 (COX-2)) [4,5]. In particular, lipopolysaccharides (LPS)-stimulated macrophages are mediated through the trans-membrane signaling receptor toll-like receptor 4 (TLR4). Nuclear factor kappa-light-chain-enhancer of activated B cells (NF-kB), a pivotal regulator in TLR4 
pathways, plays a crucial role in most inflammatory responses by stimulating the expression of pro-inflammatory genes. The activation of NF- $\mathrm{KB}$ is a consequence of degradation of inhibitors of $\mathrm{KB}$ (IKB) [6,7]. In addition, the activation of MAPK (Mitogen-activated protein kinase) pathways including p38, JNK, and ERK, leads to the activation of NF-KB [8]. The MAPK pathway also regulated another inflammatory key gene name AP-1 by phosphorylation [9]. The vertebrate zebrafish (Danio rerio) is a small tropical fish that serves as a model species in the fields of molecular genetics and developmental biology $[10,11]$. The zebrafish is an especially informative tool for studying inflammation, because it has both innate and acquired immune systems that are very similar to the mammalian immune system [12]. A large number of cytokine genes and inflammatory gene, such as TNF-a, IFN, IL-1b, IL-8, and NF-kB, which are related to the innate immune system, have been identified in zebrafish [13-15]. Ginseng is a perennial plant that grows in eastern Asia. Its root has been used traditionally as a folk medicine for improving physical stamina and modulating immune function [16,17]. Ginseng is composed mainly of ginsenosides, which contain an aglycone with a dammarane skeleton and exhibit a variety of biological benefits, including anti-tumor, anti-cardiovascular disease, and anti-inflammatory properties [18,19]. It was previously reported that the biotransformation of ginsenosides by human intestinal bacteria is closely related to the biological activity of ginsenosides. For example, protopanaxadiol is transformed to 20-O- $\beta$-D-glucopyranosyl-20(S)-protopanaxadiol (compound K) by human intestinal bacteria [20]. Compound $\mathrm{K}$ is one of the pharmacologic metabolite compounds biotransformed from ginsenosides, and it has been reported to induce health benefits through its anti-carcinogenic and anti-diabetic properties [21,22]. Lee et al. demonstrated the absorption, distribution, and metabolism of compound $\mathrm{K}$ in human. Compound $\mathrm{K}$ was absorbed into the blood $24 \mathrm{~h}$ after oral administration, with average values of $10.76 \pm 2.07 \mathrm{~h}$ (maximum drug concentration time; Tmax), $27.89 \pm 24.46 \mathrm{ng} / \mathrm{mL}$ (maximum drug concentration; Cmax), and $221.98 \pm 221.42 \mu \mathrm{g} / \mathrm{mL}$ (area under the blood concentration curve; AUC) respectively [23]. Moreover, Akao et al. investigated the absorption of compound $\mathrm{K}$ in rat plasma [24]. In our previous studies, we showed that compound K inhibited NO and prostaglandin E2 production by suppression of iNOS and COX-2 enzymes, but the precise mechanisms of action remains unknown. In the present study, to obtain insight into the biological effects of compound $\mathrm{K}$ on the inflammatory response of macrophages, we also investigated whether compound $\mathrm{K}$ could inhibit inflammatory responses in LPS-treated zebrafish.

\section{Materials and Methods}

\subsection{Materials}

Dulbecco's modified Eagle's medium (DMEM), fetal bovine serum (FBS), penicillin-streptomycin $(\mathrm{P} / \mathrm{S})$, and phosphate-buffered saline (PBS) were purchased from Gibco (Gaithersburg, MD, USA). COX-2, iNOS, p65, p-IкB- $\alpha$, IKB- $\alpha$, p-ERK, ERK, p-p38, p38, p-JNK, JNK, and GAPDH monoclonal antibodies and secondary antibodies were obtained from Cell Signaling Technology (Boston, MA, USA). The enzyme immunoassay (EIA) kits for IL- $1 \beta$ and IL- 6 were obtained from BioLegend (San Diego, CA, USA). The Maxime RT Premix Kit was purchased from iNtRON (Gyeonggi-do, Korea). COX-2, iNOS, IL-1 $\beta$, IL-6, and GAPDH oligonucleotide primers were obtained from Bioneer, Inc. (Seoul, Korea). 2,3-bis-(2-methoxy-4-nitro-5-sulfophenyl)-2H-tetrazolium-5-carboxanilide (XTT) was purchased from WEL GENE (Daegu, Korea). Compound K $(\geq 96 \%)$, TRIzol ${ }^{\circledR}$ reagent, 3-amino-4-(N-methylamino)-2', $7^{\prime}$-difluorofluorescein diacetate (DAF-FM DA), Griess reagent, and lipopolysaccharide (LPS) (Escherichia coli, serotype 0111:04) were obtained from Sigma Chemical Co. (St. Louis, MO, USA). 


\subsection{Cell Culture}

The Raw 264.7 macrophage cell line (American Type Culture Collection, CL-173) was plated and grown in DMEM with $1.5 \mathrm{~g} / \mathrm{L}$ sodium bicarbonate, $1 \% \mathrm{P} / \mathrm{S}$, and $10 \% \mathrm{FBS}$ at $37^{\circ} \mathrm{C}$ and in a humidified $5 \% \mathrm{CO}_{2}$ atmosphere. Cells were incubated with compound $\mathrm{K}$ at concentrations of 20,30 , and $40 \mu \mathrm{M}$ and then stimulated with $1 \mu \mathrm{g} / \mathrm{mL}$ LPS for the indicated time.

\subsection{Cytotoxicity Assay}

Raw 264.7 cells $\left(1 \times 10^{4}\right.$ per well) were seeded in 96-well plates and incubated in a $\mathrm{CO}_{2}$ incubator at $37^{\circ} \mathrm{C}$ for $24 \mathrm{~h}$. The cells were treated with various concentrations of compound $\mathrm{K}(0,5,10,20,40$, and $80 \mu \mathrm{M}$ ) for $24 \mathrm{~h}$, after which XTT stock solution was added to the culture medium. The cytotoxicity of compound $\mathrm{K}$ was determined using an enzyme-linked immunosorbent assay (ELISA) reader at $540 \mathrm{~nm}$ (reference wave-length $690 \mathrm{~nm}$ ).

\subsection{Nitric Oxide Determination}

Raw 264.7 cells $\left(1 \times 10^{4}\right.$ per well $)$ were plated in 96-well plates. Raw 264.7 cells were treated with various concentrations of compound $\mathrm{K}$ and then incubated with or without LPS $(1 \mu \mathrm{g} / \mathrm{mL})$ for $24 \mathrm{~h}$. Nitrites released into the culture media were determined using the Griess reaction and presumed to reflect the NO levels. Aliquots of cell culture supernatant $(100 \mu \mathrm{L})$ were mixed with $100 \mu \mathrm{L}$ Griess reagent and incubated at room temperature for $15 \mathrm{~min}$. The absorbance was then measured at $540 \mathrm{~nm}$ using an ELISA reader. Nitric oxide levels in sample were determined using a standard sodium nitrite curve.

\subsection{Enzyme-Linked Immunosorbent Assays}

Raw 264.7 cells were pretreated with compound $\mathrm{K}$ for $1 \mathrm{~h}$ and then stimulated with LPS $(1 \mu \mathrm{g} / \mathrm{mL})$ for $24 \mathrm{~h}$. Levels of IL-1 $\beta$ and IL-6 in the culture media were quantified using EIA kits (BioLegend, San Diego, CA, USA) according to the manufacturer's instructions.

\subsection{RNA Isolation and Reverse-Transcription Polymerase Chain Reaction}

Total RNA was extracted using TRIzol ${ }^{\circledR}$ reagent (Invitrogen, Carlsbad, CA, USA) according to manufacturer's method for reverse transcription polymerase chain reaction (RT-PCR) analysis. Total RNA $(1 \mu \mathrm{g})$ was used reverse transcribed to cDNA using the Maxime RT PreMix kit (Intron, Seongnam, Korea). Amplification of the target genes was performed using specific oligonucleotide primers in a normal PCR system. The primers used were as follows: iNOS, forward (5'-CCCTTCCGAAGTTTCTGGCAGCAG-3'), reverse (5'-GGCTGTCAGAGCCTCGTGGCTTTG-3'); COX-2, forward (5'-ATGCTCCTGCTTGAG TATGT- $\left.3^{\prime}\right)$, reverse (5'-CACTACATCCTGACCCACTT-3 $\left.{ }^{\prime}\right)$; IL-6, forward (5'-CCATCTCTCCGTCT CTCACC-3'), reverse (5'-AGACCGCTGCCTGTCTAAAA- $\left.3^{\prime}\right)$; IL-1 $\beta$, forward $\left(5^{\prime}-3^{\prime}\right)$, reverse (5'-CTCTGCACACTCAAACTCCAC-3'); GAPDH, forward (5'-AACTTTGGCATTGTGGAAGG- $\left.3^{\prime}\right)$, reverse (5'-ACACATTGGGGGTAGGAACA-3'). The PCR products were subjected to electrophoresis on $1.0 \%$ agarose gels, which were stained with ethidium bromide and photographed.

\subsection{Western Blot Analysis}

Raw 264.7 cells were washed with PBS buffer, lysed with lysis buffer, and then centrifuged to remove cell debris. The protein concentration of the supernatant was determined using the Bradford assay. Protein extracts (50 $\mu \mathrm{g}$ ) were separated by sodium dodecyl sulfate polyacrylamide gel electrophoresis(SDS-PAGE) and transferred to polyvinylidene difluoride membranes. The membranes were blocked and then immunoblotted with primary antibodies specific for iNOS, COX-2, p65, p-IKB- $\alpha$, IKB- $\alpha, p-E R K, E R K, p-p 38, p 38, p-J N K, J N K$, and GAPDH at $4{ }^{\circ} \mathrm{C}$ overnight. Secondary antibodies conjugated to horseradish peroxidase (1:1000) were then incubated with the blot for $1 \mathrm{~h}$. The bands 
were visualized by enhanced chemiluminescence (ECL), and the protein bands were detected using LAS image software (Fuji, New York, NY, USA).

\subsection{Zebrafish Care and Experimental Protocol}

We performed the experiments like our previous paper [25]. All zebrafish experiments were approved by the Internal Animal Ethics Committee at CHA University (IACUC140001). Embryos of zebrafish (Danio rerio) were obtained from Chungnam National University (Daejeon, South Korea) as a gift. Synchronized zebrafish embryos were collected and re-arranged using a pipet at 20 embryos/well in six-well plates containing $2 \mathrm{~mL}$ of egg water. After $7-9 \mathrm{~h}$ post fertilization (hours post-fertilization; hpf), embryos were incubated with or without $40 \mu \mathrm{M}$ concentrations of Compound $\mathrm{K}$ for $1 \mathrm{~h}$. Zebrafish were stimulated by LPS $(5 \mu \mathrm{g} / \mathrm{mL})$ for $24 \mathrm{~h}$ at $28.5^{\circ} \mathrm{C}$. The zebrafish embryos were then transferred into fresh embryo medium.

\subsection{Nitric Oxide Determination in Zebrafish}

NO levels in the inflammatory zebrafish model were measured using a fluorescent probe dye, diaminofluorophore 4-amino-5-methylanino-2,7-difluoro-fluoroescein diacetate (DAF-FM DA) [26-28]. The transformation of DAF-FM DA by NO generates highly fluorescent triazole derivatives. Following stimulation by LPS, the zebrafish larvae were transferred into 96-well plates and treated with DAF-FM DA solution $(1 \mu \mathrm{M})$ for $1 \mathrm{~h}$ in the dark at $28.5^{\circ} \mathrm{C}$. After incubation, the zebrafish larvae were rinsed in fresh zebrafish embryo medium and anesthetized with tricaine methanesulfonate solution before observation. The fluorescence intensity of individual zebrafish larvae was quantified using an ECLIPSE E600 (Nikon, Tokyo, Japan). The fluorescence was analyzed by Image J.

\subsection{Statistical Analysis}

All experiments were performed in triplicate. The data were statistically analyzed using a one-way analysis of variance (ANOVA) and Duncan's multiple range tests. All values are presented as the means \pm standard deviation (SD) values. $p$-values in the multiple comparison results (e.g., a, b, c, and d) indicate significant differences among the groups; $p<0.05$.

\section{Results}

\subsection{Effect of Compound K on RAW264.7 Cell Viability}

Figure $1 \mathrm{~A}$ shows the chemical structure of Compound K. To evaluate the cytotoxicity of compound $\mathrm{K}$, RAW 264.7 cells were treated with various concentrations of compound $\mathrm{K}$, under concentrations in previous study related with inflammation [18], and then cell viability was determined using XTT assay. Compound $\mathrm{K}$ at concentrations up to $40 \mu \mathrm{M}$ did not significantly affect RAW264.7 cell viability (Figure 1B). It was confirmed by observing cell morphology under a microscope (data not shown). Accordingly, all of the following experiments were performed within this range of compound $\mathrm{K}$ concentrations (20,30, and $40 \mu \mathrm{M})$. 
A

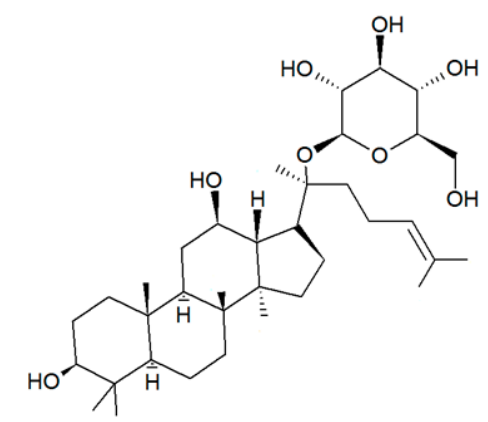

B

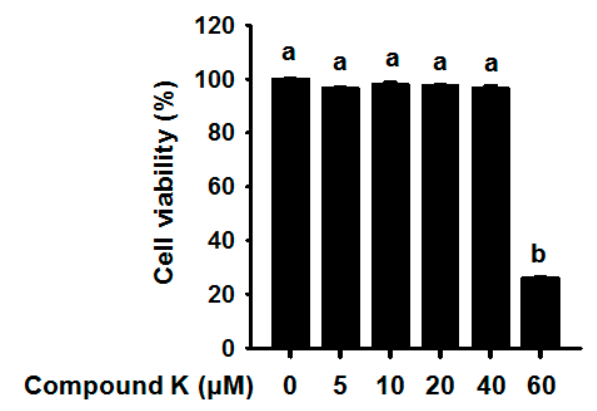

Figure 1. The chemical structure of compound $K$ and its effect on cell viability. (A) A chemical contracture of compound K. (B) Raw 264.7 cells $\left(1 \times 10^{4} /\right.$ well) were treated with Compound $\mathrm{K}(0-60 \mu \mathrm{M})$ for $24 \mathrm{~h}$. Cell viability was determined using the 2,3-bis-(2-methoxy-4-nitro5-sulfophenyl)-2H-tetrazolium-5-carboxanilide (XTT) assay. Values are means \pm S.D. of three independent experiments. $\left({ }^{\mathrm{a}} p<0.05,{ }^{\mathrm{b}} p<0.01\right.$ ).

\subsection{Inhibitory Effect of Compound K on LPS-Induced NO Production and iNOS and COX-2 Expression Levels}

To assess the inhibitory effects of compound K on LPS-induced NO production, RAW 264.7 cells were treated with various concentration of compound $\mathrm{K}$ and then incubated with or without LPS $(1 \mu \mathrm{g} / \mathrm{mL})$ for $24 \mathrm{~h}$. As shown in Figure 2A, compound K treatment in LPS-treated RAW 264.7 cells significantly inhibited the production of NO in a dose-dependent manner. From the results of RT-PCR and Western blot analysis, we found that compound K effectively suppressed LPS-induced mRNA and protein expression of iNOS, which is one of key enzymes generating NO from the amino acid L-arginine (Figure 2B,D). In addition, compound K suppressed LPS-induced COX-2 mRNA and protein levels (Figure 2B,D). Expression of COX-2 and iNOS in mRNA was reduced by $90 \%$ and $70 \%$, respectively, and in protein levels was reduced by $68 \%$ and $54 \%$, respectively, by $40 \mu \mathrm{M}$ of compound $\mathrm{K}$ (Figure 2C,E). These data indicate that compound K effectively inhibited LPS-induced inflammatory responses by suppressing the expression of iNOS and COX-2 in RAW264.7 macrophages.

\subsection{Inhibitory Effect of Compound K on LPS-Induced IL-1 $\beta$ and IL-6 Release and Their Expressions}

To investigate whether compound K could inhibit LPS-induced pro-inflammatory cytokines production, cells were pretreated with compound $\mathrm{K}$ for $1 \mathrm{~h}$ and then stimulated with LPS $(1 \mu \mathrm{g} / \mathrm{mL})$ for $24 \mathrm{~h}$. From the results of RT-PCR and EIA kit analyses, we found that LPS treatment in RAW 264.7 macrophages enhanced mRNA and release levels of pro-inflammatory cytokines IL-1 $\beta$ and IL-6 compared with those of untreated cells (Figure 3A). Our RT-PCR analysis showed that mRNA expression levels of IL-1 $\beta$ and IL-6, which are crucial inflammatory cytokines, were reduced with treatment with compound $\mathrm{K}$ (Figure $3 \mathrm{~A})$. Compound $\mathrm{K}(40 \mu \mathrm{M})$ reduced the mRNA expression levels of IL- $1 \beta$ and IL- 6 by $34 \%$ and $21 \%$, respectively, compared with the control (Figure 3B). In an enzyme immunoassay, release levels of these cytokines IL- 6 and IL-1 $\beta$ secreted from LPS-treated macrophages were significantly decreased by compound $K$ treatment in a dose-dependent way (Figure 3C). In particular, compound $\mathrm{K}$, at a concentration of $40 \mu \mathrm{M}$, effectively inhibited LPS-induced IL-1 $\beta$ release compared with those of the LPS-only control (Figure 3C). These results indicate that compound K inhibited LPS-induced pro-inflammatory cytokines production in RAW 264.7 macrophages. 
B

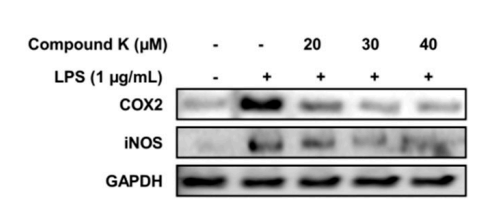

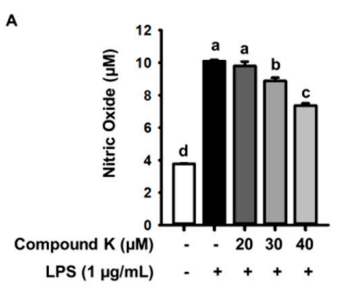

c
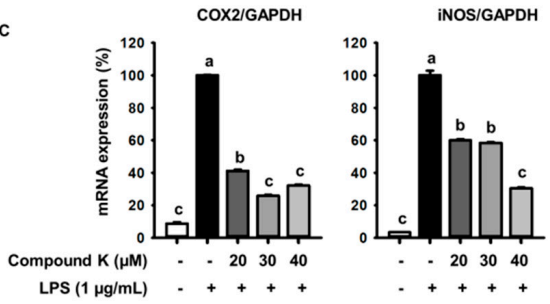

E
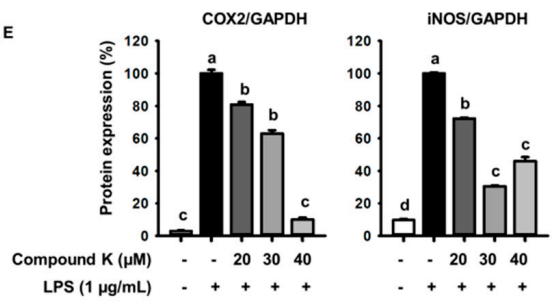

Figure 2. Inhibitory effect of compound $\mathrm{K}$ on lipopolysaccharide(LPS)-induced NO production and iNOS and COX-2 expression levels in Raw 264.7. Raw 264.7 activated by $1 \mathrm{ug} / \mathrm{mL}$ LPS was treated with compound $\mathrm{K}(20,30$ or $40 \mu \mathrm{M})$ for 4 . Raw 264.7 was treated with compound $\mathrm{K}(20,30$, or $40 \mu \mathrm{M})$ and/or LPS for $24 \mathrm{~h}$. (A) Nitric Oxide concentration in the culture media was determined using Griess reagent assay. (B) The expression of mRNA determined by using RT-PCR. (C) The mRNA expression of COX-2 and iNOS were quantified using the Image J. (D) the protein level determined by using Western blot. (E) The results were quantified using the Image J software. Values are means \pm S.D. of three independent experiments $\left({ }^{\mathrm{a}} p<0.05,{ }^{\mathrm{b}} p<0.01,{ }^{\mathrm{c}} p<0.001,{ }^{\mathrm{d}} p<0.0001\right)$.
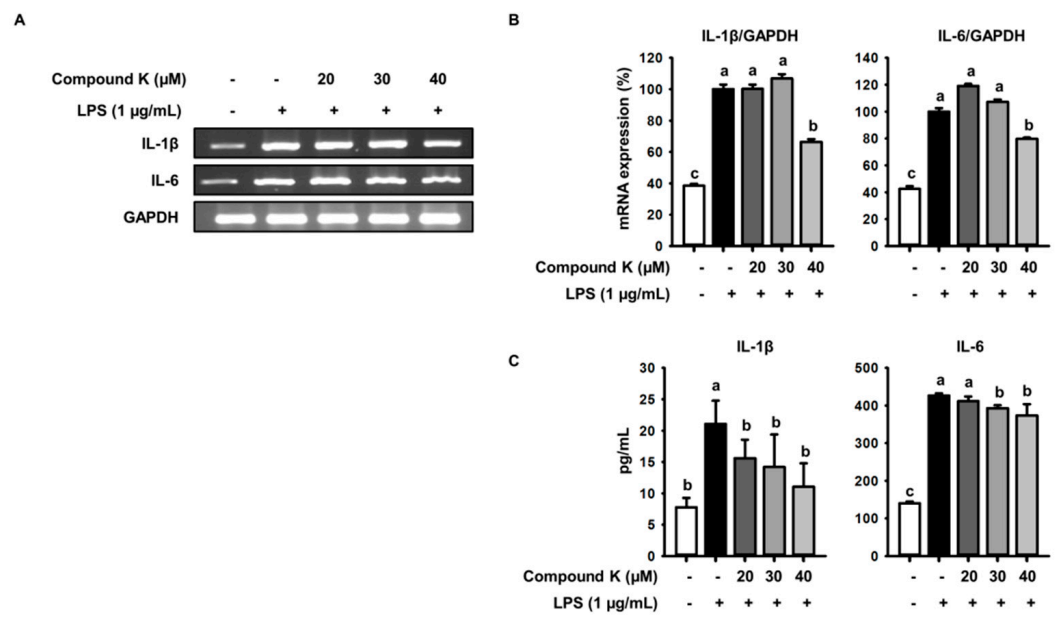

Figure 3. Effect of compound K on mRNA expression of IL-1 $\beta$ and IL-6 their secreted protein levels in LPS-stimulated Raw 264.7 cells. Cells were treated with compound K (20, 30, or $40 \mu \mathrm{M})$, LPS was then added, and cells were incubated for a further 4 or $24 \mathrm{~h}$. (A) The mRNA expression of IL-1 $\beta$ and IL-6 was determined by using RT-PCR and visualized on the gel. (B) The results were quantified using the ImageJ software. (C) Cytokine in the culture media were determined using enzyme immunoassay kit. Values are means \pm S.D. of three independent experiments $\left({ }^{\mathrm{a}} p<0.05,{ }^{\mathrm{b}} p<0.01,{ }^{\mathrm{c}} p<0.001\right)$. 


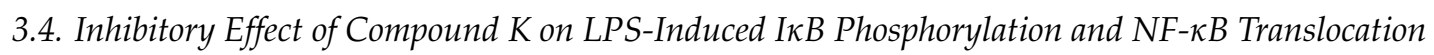

To define the molecular action of compound $\mathrm{K}$ on the inhibition of inflammatory responses, we examined translocation activity of NF- $\mathrm{kB}$, which is a key transcription factor that controls the many pro-inflammatory cytokines and genes, by analyzing translocation of NF- $\mathrm{kB}$ p 65 from the cytoplasm into the nucleus using Western blot analysis. We found that the amount of p65, a key subunit of NF- $\mathrm{kB}$, in the nuclear fraction was enhanced by LPS treatment compared with those of untreated control (Figure 4C,D). Compound K inhibited translocation of p65 in LPS-treated RAW 264.7 macrophages. In particular, compound $\mathrm{K}$ at a concentration of $40 \mu \mathrm{M}$ remarkably decreased translocation of p65 in the nuclear fraction (Figure 4C,D). Translocation of NF- $\mathrm{kB}$ into nucleus was known to be related with phosphorylation of IKB- $\alpha$ in TLR4 pathway, which is a major inflammatory pathway. We examined the phosphorylation of I $\mathrm{KB}-\alpha$, a mediator of NF- $\mathrm{kB}$ activation. Our data showed that LPS increased phosphorylated I $\kappa \mathrm{B}-\alpha$ level, but compound $\mathrm{K}$ inhibited phosphorylation of I $\mathrm{KB}-\alpha$ compared with those of the LPS control (Figure 4A,B). These results indicate that compound $\mathrm{K}$ inhibited LPS-induced inflammatory responses by the deactivation of NF- $\mathrm{kB}$ and I $\kappa \mathrm{B}-\alpha$.

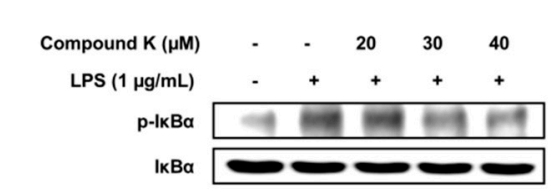

c

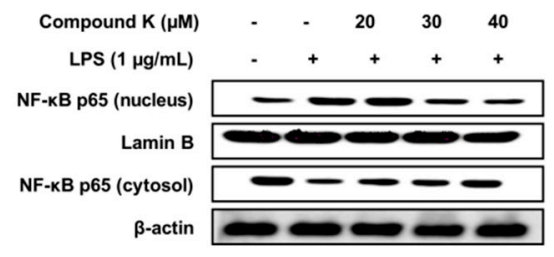

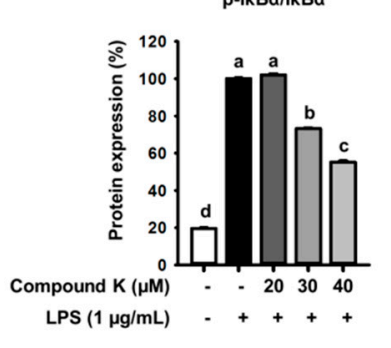

D
NF-kB p65 (cytosol)/ $\beta$-actin

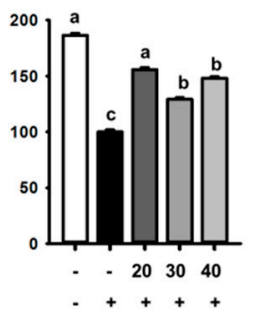

Figure 4. Effect of Compound $\mathrm{K}$ on the phosphorylation of ІкB- $\alpha(\mathrm{A})$ and the nuclear translocation of NF-KB (C). Cells were pretreated with the Compound K (20, 30, or $40 \mu \mathrm{M})$ for $1 \mathrm{~h}$ and then with LPS $(1 \mu \mathrm{g} / \mathrm{mL})$ for $15 \mathrm{~min}$. Protein levels were determined by Western blotting. (B) The results were quantified using the ImageJ software and normalized to IкB $\alpha$. (D) NF- $\kappa B$ p65 levels in the cytosol and nucleus were quantified using the ImageJ software and normalized to Lamin $B$ and $\beta$-actin, respectively. Values are means \pm S.D. of three independent experiments $\left({ }^{\mathrm{a}} p<0.05,{ }^{\mathrm{b}} p<0.01,{ }^{\mathrm{c}} p<0.001\right)$.

\subsection{Inhibitory Effect of Compound K on LPS-Induced MAPKs Activation}

MAPK signaling pathways regulate signal transduction and inflammatory mediators via activation of NF- $\mathrm{kB}$ [8]. We investigated whether compound K could inhibit LPS-induced MAPKs signaling. Since MAPK is activated through phosphorylation, we determined the phosphorylated status of JNK, ERK, p38 MAPK in RAW 264.7 macrophages using Western blot analysis. Compared with the control, higher levels of phosphorylation all three MAPKs were observed in cells treated with LPS (Figure 5A). Compound K remarkably inhibited LPS-induced phosphorylation of ERK and JNK, but phosphorylation of p38 MAPK in the LPS-treated macrophages was not decreased by compound K treatment (Figure 5A). The decrease in phosphorylation of ERK and JNK was $27 \%$ and $54 \%$, respectively, by $40 \mu \mathrm{M}$ Compound K (Figure $5 \mathrm{~B}$ ). Our result indicated that inhibition of ERK and JNK rather than p38 contributes to anti-inflammatory effect of compound $\mathrm{K}$ in LPS-induced inflammatory response. 
A

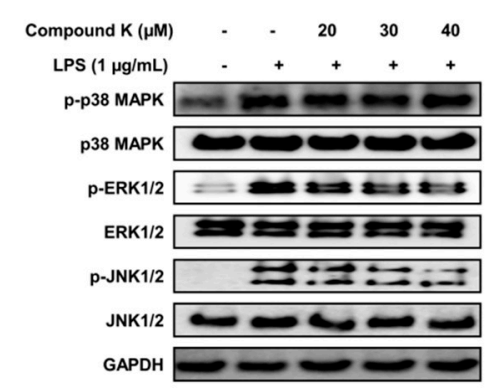

B

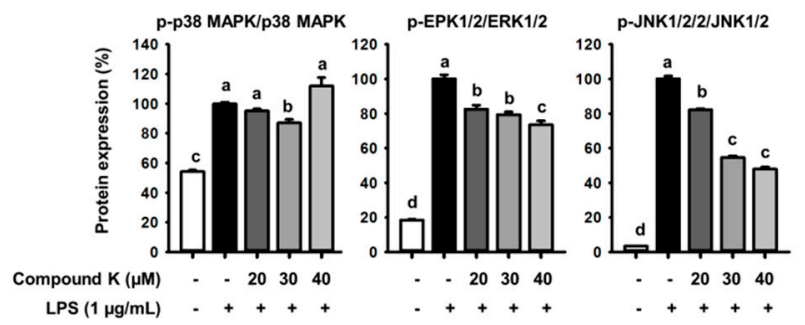

Figure 5. Inhibitory effect of compound K on the LPS-induced activation of MAP kinase in Raw 264.7 cells. Raw 264.7 cells were pretreated with compound $\mathrm{K}(20,30$, or $40 \mu \mathrm{M})$ for $1 \mathrm{~h}$ and then with LPS $(1 \mu \mathrm{g} / \mathrm{mL})$ for $15 \mathrm{~min}$. (A) Total proteins $(50 \mu \mathrm{g})$ were loaded for the Western blotting. (B) The results were quantified using the ImageJ software and normalized to those of phosphorylated forms to total protein expression. Values are means \pm S.D. of three independent experiments $\left({ }^{\mathrm{a}} p<0.05,{ }^{\mathrm{b}} p<0.01\right.$, $\left.{ }^{c} p<0.001,{ }^{\mathrm{d}} p<0.0001\right)$.

\subsection{Inhibitory Effect of Compound K on LPS-Induced NO Productions in Experimental Zebrafish Model}

Prior to measure of the NO inhibitory effect of Compound $\mathrm{K}$, we first examined its toxicity on the survival of zebrafish. The embryos of zebrafish were treated with LPS $(5 \mu \mathrm{g} / \mathrm{mL})$ and compound $\mathrm{K}(40 \mu \mathrm{M})$ for $48 \mathrm{~h}$. Compound $\mathrm{K}$ and LPS did not affect cytotoxicity on zebrafish (data not shown). Before starting the treatment, we monitored the zebrafish, including the pigmentation, the size, and shape of the yolk structure. Physical changes were not observed with all groups (data not shown). To confirm that compound $\mathrm{K}$ has anti-inflammatory activity, we investigate the anti-inflammatory effect of compound $\mathrm{K}$ in vivo using the zebrafish model. To show NO production in LPS-stimulated inflammation zebrafish model, we used a fluorescent probe dye, DAF-FM DA. As shown in Figure 6A, the level of NO production in zebrafish was increased by the LPS treatment compared with untreated control. LPS-induced elevation of NO production was significantly reduced with compound $\mathrm{K}$ treatment (Figure 6A). In particular, $40 \mu \mathrm{M}$ Compound $\mathrm{K}$ inhibited LPS-induced NO production in zebrafish by $30 \%$ compared with the LPS control group (Figure 6B). Our result showed that compound K effectively reduced LPS-induced NO production in vivo.

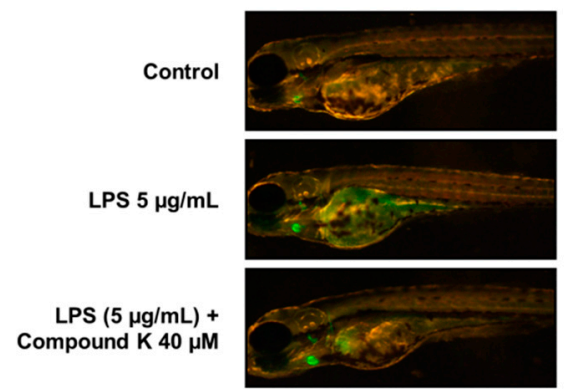

B

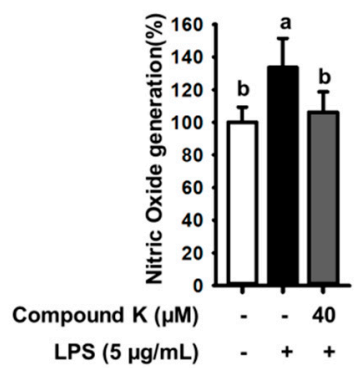

Figure 6. Effect of compound K on LPS-stimulated NO production in zebrafish embryo. The zebra fish embryos were pretreated with compound $\mathrm{K}$ for $1 \mathrm{~h}$ and then exposed to LPS (5 $\mu \mathrm{g} / \mathrm{mL})$ for $24 \mathrm{~h}$. (A) The NO generation level was measured after staining with DAF-FM-DA, and (B) fluorescence spectrophotometer was used for the quantitative analysis of NO generation by using Image J. Values are means \pm S.D. of three independent experiments $\left({ }^{\mathrm{a}} p<0.05,{ }^{\mathrm{b}} p<0.01\right)$. 


\section{Discussion}

We have demonstrated that compound $\mathrm{K}$ effectively inhibited the inflammatory response in LPS-treated RAW 264.7 macrophages and zebrafish. Our previous study compared the anti-inflammatory effects of ginsenoside $\mathrm{Rb} 1$ and compound $\mathrm{K}$ to investigate how the biotransformation of ginsenosides affects their biological activity, and we showed that compound $\mathrm{K}$, rather than $\mathrm{Rb} 1$, significantly inhibited the inflammatory response. However, the mechanisms by which compound $\mathrm{K}$ is effective against inflammation are unknown. Therefore, in this study we confirmed the anti-inflammatory effect of compound K in LPS-stimulated Raw 264.7 macrophages and zebrafish models and investigated its molecular signaling pathways. Compound $\mathrm{K}$ reduced $\mathrm{NO}$ production dose-dependently both in vivo and in vitro. Excessive levels of NO, induced by LPS in macrophages, are associated with inflammatory diseases and are involved in other negative cellular physiologies such as mutagenesis, DNA structural damage, and formation of N-nitrosoamines [29-31]. Our data provide evidence that compound K reduces LPS-induced NO production dose-dependently and down-regulates iNOS, which is closely related to the synthesis of NO. COX-2, another inflammatory marker, is also associated with the production of pro-inflammatory molecules, such as prostaglandin E2, and promotes pro-inflammatory signaling cascades. Hernandez et al. (2001) reported that COX-2 was stimulated in angiogenesis-related diseases, such as rheumatoid arthritis and psoriasis [32]. In the present study, we reconfirm that compound K effectively suppressed LPS-induced mRNA and protein expression of COX-2 in macrophages. Inflammatory cytokines play important roles in the extent of inflammation and recruit other immune cells implicated in the pathogenesis of inflammatory conditions, such as rheumatoid arthritis and septic shock [33]. IL-1 $\beta$ is an important inflammatory cytokine produced by LPS-activated macrophages. During the inflammatory response, it increased secretion of IL- $1 \beta$ leads to cell or tissue damage. IL-6, a pro-inflammatory cytokine, acts as an endogenous pyrogen in addition to its multiple effects on the immune system and particularly on hematopoiesis [34-36]. Reduced secretion of IL-1 $\beta$ and IL-6, pro-inflammatory cytokines, from macrophages may retard inflammatory responses to LPS stimulation. In the present study, IL-1 $\beta$ and IL-6 mRNA expression levels were decreased markedly in LPS-treated cells after treatment with compound $\mathrm{K}$. In addition, compound $\mathrm{K}$ significantly attenuated the release of pro-inflammatory cytokines in a dose-dependent manner. Therefore, these results indicate that compound $\mathrm{K}$ may have an anti-inflammatory effect.

The regulation of inflammatory cytokines and inflammatory responses are regulated transcriptionally by NF- $\mathrm{kB}$ transcription factors. Macrophages activated by LPS accelerate I $\mathrm{B} \alpha$ phosphorylation, which leads to its subsequent degradation [37]. After the degradation of IKB $\alpha$, the activated NF- $\mathrm{KB}$ is translocated into the nucleus and binds to NF- $\mathrm{KB}$-binding sites in the promoter regions of inflammatory mediators to induce their transcription, promoting the expression of inflammatory genes, including iNOS, COX-2, and the inflammatory cytokines, IL-6 and IL-1 $\beta$ [38]. In the present study, to evaluate the effect of compound K on NF- $\mathrm{KB}$ translocation, we determined the expression levels of phosphorylated $I \kappa B \alpha$ and nuclear and cytosolic p65 by Western blot analysis using anti-NF-kB p65 and IкB $\alpha$ antibodies. Our results showed that compound $\mathrm{K}$ suppressed the expression levels of phosphorylated $\mathrm{I} \kappa \mathrm{B} \alpha$ and inhibited p 65 translocation into the nucleus in LPS-treated cells, suggesting that compound $K$ has anti-inflammatory effects via the suppression of I $\kappa \mathrm{B} \alpha$ phosphorylation and NF- $\kappa \mathrm{B}$ translocation in LPS-stimulated Raw 264.7 cells.

MAPK signaling pathways regulate signal transduction and inflammatory mediators via activation of NF-kB [8]. This kinase family is composed of several members, including JNK, ERK, and $\mathrm{p} 38$, and is activated by phosphorylation. We examined the modulation of upstream signaling molecules related to NF- $\mathrm{kB}$ inactivation and observed that compound $\mathrm{K}$ inhibited the phosphorylation of ERK and JNK, but not p38, in LPS-stimulated macrophages. Taken together, these results indicated that compound $\mathrm{K}$ exhibits anti-inflammatory properties by down-regulating NF- $\mathrm{kB}$ and MAPK signaling pathways in LPS-stimulated RAW264.7 macrophages. 
We used zebrafish as an in vivo model system to confirm the anti-inflammatory effects of compound K. Zebrafish provide a highly informative vertebrate model system for biological research, as they show physiological similarity to mammals but can be examined in large quantities at a low cost, and their transparent body facilitates physiological examinations [39,40]. Recent studies demonstrated the utility of zebrafish as a model system for drug discovery research [41,42]. Zebrafish also possess innate and acquired immune systems similar to those of mammals). We selected 7-9 hpf larvae and treated embryo for $25 \mathrm{~h}$ with Compound $\mathrm{K}$. Especially, the anti-inflammatory effect of compounds was confirmed at the level of NO production using DAF-FM-DA stained in LPS-stimulated zebrafish [26]. Lepiller et al. demonstrated that DAF-FM DA can be used to monitor changes in NO production in zebrafish. Moreover NO was detected in between 24 and $48 \mathrm{hpf}$ [43]. Our data showed that compound K effectively reduced LPS-induced NO production in zebrafish, thus demonstrating the anti-inflammatory effect of compound $\mathrm{K}$ in vivo. To our knowledge, this is the first report demonstrating an anti-inflammatory effect of compound $\mathrm{K}$ in an experimental zebrafish model.

\section{Conclusions}

In summary, we demonstrated anti-inflammatory properties of compound $\mathrm{K}$ using in vitro and in vivo experimental models. Compound $\mathrm{K}$ effectively inhibited LPS-induced inflammatory molecules and cytokine production. Further, compound $\mathrm{K}$ was shown to inhibit inflammatory responses via suppression of NF-KB and MAPK signaling pathways. Therefore, our study provides important information that can be used towards the development of anti-inflammatory agents containing compound $\mathrm{K}$.

Author Contributions: S.-J.R., J.C., J.-S.L., H.-S.C., K.-Y.K., J.-H.H., K.-J.K., and B.-Y.L. conceptualized and designed the experiments. S.-J.R. performed and analyzed the experiments. S.-J.R., J.C., J.-S.L., and B.-Y.L. performed the experiments and wrote this manuscript. All authors read and approved the final manuscript.

Conflicts of Interest: The authors declare no conflicts of interest.

\section{References}

1. Bautista, L.E. Inflammation, endothelial dysfunction, and the risk of high blood pressure: Epidemiologic and biological evidence. J. Hum. Hypertens. 2003, 17, 223-230. [CrossRef] [PubMed]

2. Wellen, K.E.; Hotamisligil, G.S. Inflammation, stress, and diabetes. J. Clin. Investig. 2005, 115, 1111-1119. [CrossRef] [PubMed]

3. Xu, H.; Barnes, G.T.; Yang, Q.; Tan, G.; Yang, D.; Chou, C.J.; Sole, J.; Nichols, A.; Ross, J.S.; Tartaglia, L.A. Chronic inflammation in fat plays a crucial role in the development of obesity-related insulin resistance. J. Clin. Investig. 2003, 112, 1821-1830. [CrossRef] [PubMed]

4. Akira, S.; Uematsu, S.; Takeuchi, O. Pathogen recognition and innate immunity. Cell 2006, 124, 783-801. [CrossRef] [PubMed]

5. Brown, K.L.; Cosseau, C.; Gardy, J.L.; Hancock, R.E. Complexities of targeting innate immunity to treat infection. Trends Immunol. 2007, 28, 260-266. [CrossRef] [PubMed]

6. Keating, S.E.; Maloney, G.M.; Moran, E.M.; Bowie, A.G. Irak-2 participates in multiple toll-like receptor signaling pathways to nfkb via activation of traf6 ubiquitination. J. Biol. Chem. 2007, 282, 33435-33443. [CrossRef] [PubMed]

7. O'Neill, L.A. Tlrs: Professor mechnikov, sit on your hat. Trends Immunol. 2004, 25, 687-693. [CrossRef] [PubMed]

8. Vanden Berghe, W.; Plaisance, S.; Boone, E.; De Bosscher, K.; Schmitz, M.L.; Fiers, W.; Haegeman, G. P38 and extracellular signal-regulated kinase mitogen-activated protein kinase pathways are required for nuclear factor-kappab p65 transactivation mediated by tumor necrosis factor. J. Biol. Chem. 1998, 273, 3285-3290. [CrossRef] [PubMed]

9. Von Knethen, A.; Callsen, D.; Brüne, B. Nf-kb and ap-1 activation by nitric oxide attenuated apoptotic cell death in raw 264.7 macrophages. Mol. Biol. Cell 1999, 10, 361-372. [CrossRef] [PubMed] 
10. Driever, W.; Solnica-Krezel, L.; Schier, A.; Neuhauss, S.; Malicki, J.; Stemple, D.; Stainier, D.; Zwartkruis, F.; Abdelilah, S.; Rangini, Z. A genetic screen for mutations affecting embryogenesis in zebrafish. Development 1996, 123, 37-46. [PubMed]

11. Kimmel, C.B. Genetics and early development of zebrafish. Trends Genet. 1989, 5, 283-288. [CrossRef]

12. Trede, N.S.; Zapata, A.; Zon, L.I. Fishing for lymphoid genes. Trends Immunol. 2001, 22, 302-307. [CrossRef]

13. Correa, R.G.; Tergaonkar, V.; Ng, J.K.; Dubova, I.; Izpisua-Belmonte, J.C.; Verma, I.M. Characterization of nf-kappa b/i kappa b proteins in zebra fish and their involvement in notochord development. Mol. Cell. Biol. 2004, 24, 5257-5268. [CrossRef] [PubMed]

14. Hermann, A.C.; Kim, C.H. Effects of arsenic on zebrafish innate immune system. Mar. Biotechnol. (N. Y.) 2005, 7, 494-505. [CrossRef] [PubMed]

15. Rojo, I.; de Ilarduya, O.M.; Estonba, A.; Pardo, M.A. Innate immune gene expression in individual zebrafish after listonella anguillarum inoculation. Fish Shellfish Immunol. 2007, 23, 1285-1293. [CrossRef] [PubMed]

16. Shibata, S.; Fujita, M.; Itokawa, H.; Tanaka, O.; Ishii, T. Studies on the constituents of japanese and chinese crude drugs. Xi. Panaxadiol, a sapogenin of ginseng roots. Chem. Pharm. Bull. 1963, 11, 759-761. [CrossRef] [PubMed]

17. Park, E.H.; Yum, J.; Ku, K.B.; Kim, H.M.; Kang, Y.M.; Kim, J.C.; Kim, J.A.; Kang, Y.K.; Seo, S.H. Red ginseng-containing diet helps to protect mice and ferrets from the lethal infection by highly pathogenic h5n1 influenza virus. J. Ginseng Res. 2014, 38, 40-46. [CrossRef] [PubMed]

18. Choi, K.; Kim, M.; Ryu, J.; Choi, C. Ginsenosides compound k and rh(2) inhibit tumor necrosis factor-alpha-induced activation of the nf-kappab and jnk pathways in human astroglial cells. Neurosci. Lett. 2007, 421, 37-41. [CrossRef] [PubMed]

19. Lee, C.H.; Kim, J.-H. A review on the medicinal potentials of ginseng and ginsenosides on cardiovascular diseases. J. Ginseng Res. 2014, 38, 161-166. [CrossRef] [PubMed]

20. Akao, T.; Kida, H.; Kanaoka, M.; Hattori, M.; Kobashi, K. Intestinal bacterial hydrolysis is required for the appearance of compound $\mathrm{k}$ in rat plasma after oral administration of ginsenoside rb1 from panax ginseng. J. Pharm. Pharmacol. 1998, 50, 1155-1160. [CrossRef] [PubMed]

21. Han, G.C.; Ko, S.K.; Sung, J.H.; Chung, S.H. Compound k enhances insulin secretion with beneficial metabolic effects in db/db mice. J. Agric. Food Chem. 2007, 55, 10641-10648. [CrossRef] [PubMed]

22. Wakabayashi, C.; Murakami, K.; Hasegawa, H.; Murata, J.; Saiki, I. An intestinal bacterial metabolite of ginseng protopanaxadiol saponins has the ability to induce apoptosis in tumor cells. Biochem. Biophys. Res. Commun. 1998, 246, 725-730. [CrossRef] [PubMed]

23. Lee, J.; Lee, E.; Kim, D.; Lee, J.; Yoo, J.; Koh, B. Studies on absorption, distribution and metabolism of ginseng in humans after oral administration. J. Ethnopharmacol. 2009, 122, 143-148. [CrossRef] [PubMed]

24. Akao, T.; Kanaoka, M.; Kobashi, K. Appearance of compound k, a major metabolite of ginsenoside rb1 by intestinal bacteria, in rat plasma after oral administration-measurement of compound k by enzyme immunoassay. Biol. Pharm. Bull. 1998, 21, 245-249. [CrossRef] [PubMed]

25. Ryu, S.J.; Choi, H.S.; Yoon, K.Y.; Lee, O.H.; Kim, K.J.; Lee, B.Y. Oleuropein suppresses lps-induced inflammatory responses in raw 264.7 cell and zebrafish. J. Agric. Food Chem. 2015, 63, 2098-2105. [CrossRef] [PubMed]

26. Lee, J.-H.; Ko, J.-Y.; Kim, E.-A.; Hwang, E.-K.; Park, C.S.; Lee, J.-S.; Kim, C.-Y.; Lee, H.-S.; Kang, H.-K.; Cha, S.-H. Identification and large isolation of an anti-inflammatory compound from an edible brown seaweed, undariopsis peterseniana, and evaluation on its anti-inflammatory effect in in vitro and in vivo zebrafish. J. Appl. Phycol. 2017, 29, 1587-1596. [CrossRef]

27. Lee, S.-H.; Ko, C.-I.; Jee, Y.; Jeong, Y.; Kim, M.; Kim, J.-S.; Jeon, Y.-J. Anti-inflammatory effect of fucoidan extracted from ecklonia cava in zebrafish model. Carbohydr. Polym. 2013, 92, 84-89. [CrossRef] [PubMed]

28. Lee, S.-H.; Yang, H.-W.; Ding, Y.; Wang, Y.; Jeon, Y.-J.; Moon, S.-H.; Jeon, B.-T.; Sung, S.-H. Anti-inflammatory effects of enzymatic hydrolysates of velvet antler in raw 264.7 cells in vitro and zebrafish model. EXCLI J. 2015, 14, 1122-1132. [PubMed]

29. Arroyo, P.L.; Hatch-Pigott, V.; Mower, H.; Cooney, R. Mutagenicity of nitric oxide and its inhibition by antioxidants. Mutat. Res. Lett. 1992, 281, 193-202. [CrossRef]

30. Miwa, M.; Stuehr, D.J.; Marletta, M.A.; Wishnok, J.S.; Tannenbaum, S.R. Nitromation of amines by stimulated macrophages. Carcinogenesis 1987, 8, 955-958. [CrossRef] [PubMed] 
31. Wink, D.A.; Kasprzak, K.S.; Maragos, C.M.; Elespuru, R.K.; Misra, M.; Dunams, T.M.; Cebula, T.A.; Koch, W.H.; Andrews, A.; Allen, J.S. DNA deaminating ability and genotoxicity of nitric oxide and its progenitors. Science 1991, 1001-1003. [CrossRef]

32. Hernández, G.L.; Volpert, O.V.; Íñiguez, M.A.; Lorenzo, E.; Martínez-Martínez, S.; Grau, R.; Fresno, M.; Redondo, J.M. Selective inhibition of vascular endothelial growth factor-mediated angiogenesis by cyclosporin a: Roles of the nuclear factor of activated $t$ cells and cyclooxygenase 2. J. Exp. Med. 2001, 193, 607-620. [CrossRef] [PubMed]

33. McInnes, I.B.; Schett, G. Cytokines in the pathogenesis of rheumatoid arthritis. Nat. Rev. Immunol. 2007, 7, 429-442. [CrossRef] [PubMed]

34. Molloy, R.; Mannick, J.; Rodrick, M. Cytokines, sepsis and immunomodulation. Br. J. Surg. 1993, 80, $289-297$. [CrossRef] [PubMed]

35. West, M.A.; Seatter, S.C.; Bellingham, J.; Clair, L. Mechanisms of reprogrammed macrophage endotoxin signal transduction after lipopolysaccharide pretreatment. Surgery 1995, 118, 220-228. [CrossRef]

36. Van Snick, J. Interleukin-6: An overview. Annu. Rev. Immunol. 1990, 8, 253-278. [CrossRef] [PubMed]

37. Dixit, V.; Mak, T.W. Nf-kb signaling: Many roads lead to madrid. Cell 2002, 111, 615-619. [CrossRef]

38. Tak, P.P.; Firestein, G.S. Nf-kappab: A key role in inflammatory diseases. J. Clin. Investig. 2001, $107,7-11$. [CrossRef] [PubMed]

39. Eisen, J.S. Zebrafish make a big splash. Cell 1996, 87, 969-977. [CrossRef]

40. Fishman, M.C. Zebrafish genetics: The enigma of arrival. Proc. Natl. Acad. Sci. USA 1999, 96, 10554-10556. [CrossRef] [PubMed]

41. Den Hertog, J. Chemical genetics: Drug screens in zebrafish. Biosci. Rep. 2005, 25, 289-297. [CrossRef] [PubMed]

42. Pichler, F.B.; Laurenson, S.; Williams, L.C.; Dodd, A.; Copp, B.R.; Love, D.R. Chemical discovery and global gene expression analysis in zebrafish. Nat. Biotechnol. 2003, 21, 879-883. [CrossRef] [PubMed]

43. Lepiller, S.; Laurens, V.; Bouchot, A.; Herbomel, P.; Solary, E.; Chluba, J. Imaging of nitric oxide in a living vertebrate using a diaminofluorescein probe. Free Radic. Biol. Med. 2007, 43, 619-627. [CrossRef] [PubMed]

(C) 2018 by the authors. Licensee MDPI, Basel, Switzerland. This article is an open access article distributed under the terms and conditions of the Creative Commons Attribution (CC BY) license (http:/ / creativecommons.org/licenses/by/4.0/). 